\title{
Introduction
}

This book is on the developments that have transformed the economic, political and cultural coordinates of business activity, led to new forms of interest representation and changed the relationship between government and business in Turkey in the post-1980 period. The reshaping of the Turkish business environment is part of a process of transformation taking place against the historical background set by the twentiethcentury experience of economic development and cultural change in the country. This, however, has been a transformation that could only take place through the interaction between historically determined domestic factors and the international ones brought about by the global changes that began in the 1970s and led to the emergence of a new form of capitalism. Our analysis of the Turkish business environment is situated in the international context of this new capitalist order.

The new capitalism has emerged through a vast tide of institutional reforms that have changed, in Polanyian terms, "the place of the economy" 1 in all societies throughout the world. Keynesian demand management and welfare state practices in developed Western countries, national developmentalism in the periphery and socialist planning in the countries governed by communist parties were swept away as markets spread to the areas previously beyond the orbit of exchange relations. In this process, the range of economic policy choices at the national level was narrowed by an international context in which all countries had to accept the imperatives of international competitiveness and fiscal austerity to avoid the risk of capital flight and financial crisis. The global transformation also occasioned important changes in the configuration of business interests and the political and cultural coordinates of business activity. Industrial production was relocated to less-developed areas, business enterprises were restructured, and state-society relations were reshaped as new forms of capitalist regulation emerged with different types of responsibility and power sharing between governmental and non-governmental organizations (NGOs). At the cultural level, there was a globally observed change in the place of religion in different societies. Religion did not only remain important through economic globalization, it also became a fundamental source of political tension as well as an 
important element of economic and social solidarity among different groups and a rationale for philanthropic activities carried out by individuals or organizations. The debates around the "return of public religion" and "post-secularism" reflected this renewed salience of religion in the culture of the new capitalism.

Turkey constitutes a fruitful case to explore the manifestations of these developments in the business environment and to analyze their economic and political implications. In the post- 1980 period, Turkey's protectionist economic system, where business development relied heavily on state intervention, was replaced by a market-driven system integrated with the world economy. Manufacturing activity and exports of manufactured goods increased, small- and medium-sized enterprises (SMEs) acquired a novel significance and previously unindustrialized regions gained a new industrial vitality. As in many other late industrializing countries that went through similar transformations in the same period, economic change occurred in a conjuncture where the former political regime was critically re-evaluated and the reform of the existing state structure had come to the agenda. In other words, the change went beyond the economic policy environment and economic institutions, affecting the political regime itself. In Turkey, debates on the political regime change were particularly intense because of the rise of Islamic politics, which challenged the secularist character of the republican regime and affirmed religious identity as an essential component of the demands for democratization.

The extension of industrial production to some Anatolian provinces, where local business people have acquired a more important position in an economy previously dominated by big enterprises located in a few industrial centers, has received special attention in studies of contemporary Turkish political economy. ${ }^{2}$ The popular press has published enthusiastic accounts of the rise of "Anatolian tigers," 3 while the academic literature has investigated the political implications of the changes in the business community. The new Anatolian business people have been praised for their competitiveness and non-reliance on state support. The Islamic mentality and outlook of these business people have been widely discussed as variables in studies of the rise of political Islam and the compatibility of Islam with capitalist development and political democracy. Hence, some scholars have suggested a causal relationship between the emergence of a new conservative bourgeoisie and the rise to power of the "moderately" Islamic Justice and Development Party (Adalet ve Kalkınma Partisi, AKP) in 2002. ${ }^{4}$

Notwithstanding several important exceptions, ${ }^{5}$ the developments in Turkish political economy have, in general, been discussed around these 
themes and have acquired a particular significance in an international political environment dominated by the fear of "radical Islam." In this environment, the Turkish way of combining "moderate Islam" with rational economic management and political democracy has been presented as a model for other Muslim countries. In the ideologically charged atmosphere of these debates, the following questions pertaining to the emergence and nature of the "Turkish model" have not attracted much attention: Does the role of the government in the process of capital accumulation and in business life become less important after Turkey's insertion in the world economy? Are big business enterprises located in developed metropoles no longer important actors in the business scene? Is the emphasis placed on the emergence of provincial Anatolian business people sufficient to understand the changing configuration of interests and the new types of alliances and conflicts that characterize the new Turkish business environment? What are the political processes that have contributed to the making of the "conservative Muslim bourgeoisie"? What roles do non-governmental actors, business associations in particular, play in this process?

In this book, we attempt to answer these questions and highlight the tensions and conflicts that define a highly polarized business environment. We insist on the political sources and implications of this polarization as we address the familiar and still very pressing questions concerning the relationship between religion and capitalism and between capitalism and democracy.

In our investigation of the Turkish case, we draw on analyses of capitalist globalization that address the changing character of statesociety relations and discuss the new actors and forms of political action. We also revisit the debates on the role of religion in capitalist development in order to explore the way in which the "spirit of the new capitalism" is manifest in Turkey. Before we discuss the way we engage with and attempt to contribute to different currents of analysis in these areas, however, we will present a brief methodological note to clarify how we use the terms "capitalism" and "capitalist class," how we perceive the role of history in social analysis and how we imagine the relationship between politics and society.

\section{A BRIEF METHODOLOGICAL NOTE}

Our investigation of the Turkish business environment is an attempt to understand capitalism beyond its universal and unchanging characteristics by exploring its historical transformations and societal variations. Our 
objective is to contribute to the analysis of a particular historical form of capitalism in a given society. Without denying the empirical validity of the global developments that limit government leverage in determining the balance of power in society and that enhance the influence of capital on policy processes, we try to go beyond the interpretations of the recent economic globalization as a politically guided process of restoring capitalist class power, which was restrained in the previous context of "organized" or "regulated" capitalism. ${ }^{6}$ We insist that capital cannot be treated as a homogeneous entity and capitalist power cannot be analyzed without due attention to the changes that affect its configuration and the ways in which it is used. As several writers have argued, sectors of activity, the orientation toward domestic or international markets, regional location and the scale of operations of business enterprises are significant factors that shape the impact of transformations at the global and domestic levels of these enterprises. ${ }^{7}$ We argue that, in addition to differences of economic interest, the business community might also be divided by the different political positions they take vis-à-vis the developments in the country or along the lines of cultural identity. The relationship between the economic determinants of business interest and power might be articulated with such political and cultural factors in a relationship that could not always be reduced to a unidirectional causality. Non-economic determinants of the way different class actors are affected by and act to influence economic, social and political processes might appear in new forms and assume a novel importance, especially in periods of major transformation.

Since our investigation of the Turkish business environment is undertaken in a period of transformation, we find it important to remember Karl Polanyi's observations about the inadequacy of class analysis during periods of rapid social change:

Given a definite structure of society, the class theory works, but what if that structure itself undergoes change? ... neither the birth nor the death of classes, neither their aims nor the degree to which they attain them; neither their co-operations nor their antagonisms can be understood apart from the situation of the society as a whole. ${ }^{8}$

Global transformations of the last few decades have reshaped the contours of the previous institutional setting of capitalist relations and changed "the situation of the society as a whole" throughout the world. The end result was not, however, a worldwide systemic convergence, and several comparative frames of analysis have been developed to draw attention to the institutional variation among different capitalist societies. The "varieties 
of capitalism" (VoC) approach ${ }^{9}$ for example, has insisted on institutional inertia or path dependency to highlight the continuing difference between liberal market economies (LMEs) and coordinated market economies (CMEs). Other writers have suggested a broader comparative framework by highlighting the existence of other varieties of capitalism where the role played by the state is much more important than in LMEs or CMEs. Hence, the atypical cases of European countries such as France, Spain and Italy or the cases of late industrializing countries such as Taiwan and Korea are introduced into the analysis to demonstrate distinctive patterns of state action and interaction with social actors. ${ }^{10}$

The debates around typologies of institutional structure and some criticisms of the original essay on the VoC by Hall and Soskice have brought to the fore certain questions that are central to the methodological framework that we use in this study. One of these questions concerns the way social analysis should deal with historical change. While the original $\mathrm{VoC}$ approach used notions of institutional inertia, path dependency and economic constraint to explore systemic continuity and change, some writers argue that the approach tends to substitute comparative statics for truly dynamic historical analysis. These critiques have pointed out that neither the shift from one variety of capitalism to another nor the responses to change determined by concerns about economic efficiency constitute an adequate focus for dynamic analysis. ${ }^{11}$ The role of political factors in determining the direction of historical change constitutes another question raised by writers who take issue with the tendency of the VoC approach to evaluate systemic diversity without dealing with questions pertaining to conflicts of interest, relations of power as well as ideas and discursive practices. ${ }^{12}$

In this book, we follow a methodological approach that draws on insights from the historical institutionalist tradition ${ }^{13}$ and carry out our analysis with the understanding that history is important for social analysis because the developments analyzed take place there and now. The legacy of a country's past informs the attitudes of policy makers and economic actors. Yet it also remains true that choices made by these actors are determined by the constraints as well as the opportunities that emerge in the current setting of the international economy. In a dynamically changing environment, there and now act upon each other in a way that affects the parameters of the societally specific and the globally similar. To meet the challenge, social analysis has to explore the patterns of interaction between the transformations observed both at the domestic and international levels.

We analyze the Turkish case by arguing that the outcome of the transformation in the institutional setting of capitalist relations is not 
determined independently from the role of political action, which has taken place in a historically shaped institutional context. Political action also opens the transformation to critical scrutiny as well as attempts to modify this context to better respond to the challenges and to take advantage of the opportunities presented by a new environment. Interests play a role in this process, but so do ideas about what kind of change is possible and desirable. These interests and ideas do not emerge in consensus; conflict and controversy, rivalries and alliances as well as the attempts at persuasion are important, as they are typically present in most societies going through transformation. In our approach to the role of politics in historical developments in Turkey, we attempt to analyze the particular articulation of the political with the economic and the cultural rather that proceeding with a social imagination where the economy and culture are conceptualized as the realm of natural phenomena either determining the character of political intervention or being subjected to the state as it interferes in the natural course of human affairs. ${ }^{14}$ Without denying the undoubtedly important role that interests, values and beliefs play in determining socioeconomic and political processes, we attempt to understand the role of politics in defining the ways in which these interests, values and beliefs are interpreted and manifested in human behavior and in the social outcomes that result from such behavior. To this end, we do not only insist on the "society shaping role of the state," but we also draw attention to different forms of political action taken by business actors who, in the context of the new capitalism in Turkey, have appeared as active agents in politically motivated processes and have contributed to the re-shaping of the business environment through their influence on the emerging cleavages along the lines of interest and outlook. We do not, in other words, perceive politics as strictly located in the realm of the state or see the state as the only political actor. The discussion that we present in the following section explains why a change in the perception of politics is required to thoroughly analyze global transformations in state-society relations and their reverberations in the Turkish context.

\section{CHANGING FORMS OF STATE INTERVENTION AND THE SHIFTING BOUNDARIES OF THE POLITICAL REALM}

The change in the character of state-society relations constitutes a central component of the transformations ushered in by economic globalization. As far as the politics of state intervention is concerned, economic 
globalization had gone through two phases by the time of the global economic crisis of 2008, which might shape the future evolution of capitalist economies. During its initial stages, from the second half of the 1970s through the 1980s, the global transition to a new system of capitalist regulation was accompanied by the ascendance of what may be called an ideology of market fundamentalism. Hayek's warnings against both the futility of - and the dangers entailed by - government intervention in the economy marked an ideological environment where the "rhetoric of reaction" analyzed by Hirschman appeared as an integral component of political debate. ${ }^{15}$ Ronald Reagan summed up this ideological environment in his first inaugural address in January 1981: "Government is not the solution to our problems, government is the problem."

However, this type of market fundamentalism did not last very long. In the 1990s, dissatisfaction with market orthodoxy represented by the so-called Washington Consensus led to a search for mechanisms of "good governance" within international policy circles. The 1997 World Development Report of the World Bank is an important benchmark in the transition from "Washington" to a "Post-Washington Consensus." ${ }^{16}$ Some writers have interpreted the significance accorded to the concept of "governance" in policy discourse as a signal of the increased willingness to take the political dimension of development into account. The following statement by Carlos Santiso is a typical example of this interpretation:

The recognition of the crucial role of the state in economic management and in the regulation and supervision of financial markets has conferred acute significance to the strengthening of good governance. Markets require a legal and regulatory framework that only governments can provide appropriate legal and financial institutions and regulations ensuring sound financial and banking regulations, establishing oversight bodies and regulatory agencies. ${ }^{17}$

Joseph E. Stiglitz, the winner of the 2001 Nobel Prize in economics, also commented on the changed outlook, which he saw as a very welcome concern with the objectives and instruments of economic policy. ${ }^{18}$

The change in the international policy environment may well be interpreted as a development vindicating Polanyi's argument that a good deal of state intervention is required both to create a free market economy and to contain its destructive impact on the society. As he observed in his analysis of nineteenth-century developments:

The road to the free market was opened and kept open by an enormous increase in continuous, centrally organized and controlled interventionism. To 
make Adam Smith's "simple and natural liberty" compatible with the needs of human society was a most complicated affair. ${ }^{19}$

The recent wave of market expansion, too, proceeded with financial liberalization, labor market de-regulation and widespread commercialization of agriculture and social services. Nonetheless, the state remained an important actor in the economy and society. In this regard, Polanyi's analysis of state intervention as a crucial factor in the expansion of market relations is especially relevant for studies of contemporary capitalism. However, the patterns of state-society relations that emerged through the economic globalization of the late twentieth century might be difficult to understand within the confines of a strictly Polanyian approach.

Polanyi's approach is based on a model of "societies and economic systems" that incorporates different principles of socioeconomic integration and their accompanying institutional patterns. In this model, the principles of state redistribution, reciprocity relations in their informal and personal character, and market exchange determine, with societally different degrees of relative significance, the way "the economy is instituted." The institutional realms in which these principles operate remain clearly separate from each other. ${ }^{20}$ According to Polanyi, the nineteenth-century market economy was a historically exceptional phenomenon because it was entirely dominated by market relations and institutions. The notion of the "disembeddedness" of the economy from society, which Polanyi used to highlight the historically unique character of the nineteenth-century developments he analyzed, refers to the domination of the economy by a system of markets that were not subjected to social control mechanisms. In other words, according to Polanyi, although the market economy was created by state intervention, it remained "self-regulating."

It now seems necessary to go beyond the emphasis placed on the self-regulating character of the market economy in The Great Transformation to explore the systems of governance that characterize the new capitalism. These systems of governance involve political authorities, private business people and NGOs at the national and local levels and, as such, they indicate a certain "metamorphosis" of the state, according to Susan Strange. ${ }^{21}$

One aspect of this metamorphosis is the increasing significance of the economic role played by municipal governments and local branches of the central government administration. The discussions around the concept of a "rescaling of the state" have drawn attention to this development, leading to a series of critical questions concerning the actual 
significance of trends toward the rescaling of the state and the extent to which these trends involve the devolution of authority to lower levels of government and define a process of decentralization. ${ }^{22}$ These questions remain relevant and need to be pursued through an analysis of the relationships between governmental and non-governmental actors at different spatial levels.

Policies advocated by international organizations and implemented in most societies include revenue-sharing agreements in public contracts with private investors in infrastructure, public-private-NGO partnerships to supply of goods and services and public funding of the private provision of education, health and social housing. With this "blurring of boundaries" between the public and the private or between the governmental and the non-governmental observed in its relational matrix, the new system of capitalist governance does not easily lend itself to models of interaction between different social actors situated in distinct institutional realms of the state, the market and civil society. ${ }^{23}$

The nature of this emerging institutional frame of capitalist economies has been explored in different currents of analysis such as those that critically engage with the Regulation School, ${ }^{24}$ investigate the nature of "neoliberalism" 25 or refer to the "privatization of the state." 26 Wolfgang Streeck highlights the difference between "Durkheimian" obligatory institutions and "Williamsonian" market-responsive and market-driven institutions constructed by market participants in order to increase the efficiency of their exchange relations, and he discusses the transformation of postwar capitalism in Germany in terms of a shift from the former type of institutions to the latter. While Streeck insists that the institutional transformation in question has signaled a retreat of public institutions (including the state), his analysis of the change in the positions and prerogatives of governmental groups and NGOs indicate that the areas formerly regulated by the state have not simply been absorbed by the market, but are now subject to a new form of regulation in which market actors assume public roles. ${ }^{27}$

Such new forms of responsibility and power sharing in different societies involve more than market actors, and they call for a change in the perception of the state as the only political actor. The expanding domain of civil society initiatives constitutes an aspect of a new environment where political action by non-state actors has acquired new significance. The increasingly significant involvement of NGOs in politics has not necessarily undermined the role of governments and political parties, but it has forced them to interact more closely with social movements seeking to occupy or create a sphere of the political within civil society. ${ }^{28}$ Again, the change is not necessarily in the direction of a 
retreat of the state, and it calls for a reconsideration of the view that civil society exists in an autonomous domain outside the realm of state power, which it often tries to check or by which it is negatively affected. Several writers have, in fact, contested these assumptions about civil society by drawing on empirical observations of the political determinants and implications of civil society activity in different societies. ${ }^{29}$ Levy refers to developments in France to challenge the idea that the civil society operates in "a more or less zero-sum relation to state." He argues that the "relationship between the state and civil society is reciprocal and symbiotic." 30 The relationship in question can, of course, take on different forms in different societies, and political party politics can significantly influence the way it is shaped, as we will see in the case of Turkey.

In Turkey, new forms of governance that brought along a shift in the boundaries of the political were reflected in the changing nature of government-business relations and the roles played by business associations. As in many other late industrializing countries, private-sector development in twentieth-century Turkey was marked by the crucial role played by the state. ${ }^{31}$ Corporatism was a dominant feature of the formal institutional frame of interest representation in the early stages of industrialization in Turkey. The chambers of industry and commerce were the officially recognized, licensed and subsidized organs of interest representation; membership in the chambers was - and still is - compulsory, and voluntary associations were largely absent from the scene until the 1970s. However, the Turkish experience did not fully conform to Schmitter's observation that state corporatism is "a defining element of, if not structural necessity for, the anti-liberal, delayed capitalist, authoritarian, neo-mercantilist state." 32 The Turkish business environment was characterized, first and foremost, by the nature of the relations between the government and big business, which were carried outside the frame of organized interest representation. The relations of the latter with the government were characterized by particularism and clientelism, but were also rife with tensions. To the extent that one can see these two parties as partners in development, the dominant partner was surely the one holding political power. ${ }^{33}$

These relations gradually began to change in the 1960s with the development of the private sector. The existing institutional frame of interest representation became increasingly restricting for big business enterprises, and in the 1970s voluntary business associations began to have a significant presence in the policy arena. The establishment of the Turkish Industrialists and Business Association (Türk Sanayici ve $\dot{I}_{s}$ Adamları Derneǧi, TÜSIAD) in 1971 introduced important changes in 
government-business relations. Big business, represented by TÜSİAD, seemed to be less dependent on the state and much less timid in its criticism of government policy. One could very well expect further changes in the same direction in the context of the new marketdominated economy inserted in the global market and the ensuing decline of state autonomy. This, however, was not the outcome of the global market-oriented transformation enthusiastically supported by the big business community. The power and influence of the government on the direction of business development has not become less important, neither have the tensions in government-business relations disappeared.

In Turkey, the market-led re-orientation of economic development proceeded without putting in place proper regulatory mechanisms. This engendered a series of problems that threatened economic stability. The problems surfaced in the form of massive economic crises in 1994, 1999 and 2001. When the last crisis broke, the government invited a highranking Turkish bureaucrat from the World Bank to implement the macroeconomic stabilization policies imposed by the International Monetary Fund (IMF), as well as to lead a comprehensive institutional reform process as the minister of state for the economy. The reforms implemented conformed to the basic tenets of the "good governance phase" of contemporary capitalism. The objective was mainly to create an institutional structure for the proper management of the economy by an autonomous bureaucracy without the discretionary intervention of politicians. The introduction of a series of regulatory mechanisms, especially the establishment of Independent Regulatory Agencies (IRAs), was effective in controlling the crisis and would later protect the financial system against future disruptions. However, the government continued to play an important role in economic life and influenced patterns of capital accumulation.

Many of the incentives from which business people previously benefited were no longer available. Nevertheless, some of them remained and new ones, which were just as important in their capacity to affect business activity, appeared in the new environment. One important change in the new setting of government-business relations was the increased economic prerogatives of the local branches of the central government as well as the municipalities. This change was consistent with global trends of rescaling the state, and it introduced a new element in the dynamics of government-business relations without undermining the significance of the political element in private-sector development. SMEs, just like big enterprises, could benefit from this new type of government intervention. Moreover, the old incentive structure, which had been designed solely with the needs of big industry in mind, was 
modified to include certain instruments specifically designed to support SME development. It would not be unjustified to suggest that, for the first time in Turkey's republican history, the government became a significant actor in the economic activities of SMEs without losing its importance for big business. In the new environment, the dynamics of government-business relations have evolved and now may be analyzed in terms of the interaction between holders of political and economic power. While the government remained an important actor in business life, business people, who previously avoided taking explicit political positions in party politics, began to appear as political actors.

Through the post-1980 transformations in Turkey, the involvement of business in party politics appeared as a new and important aspect of state-society relations. In this regard, it is possible to suggest that the new pattern of government-business relations in Turkey shares similarities with the historical patterns in Italy and Greece, which are analyzed with reference to a party-state model or the "partyness" of interest politics. ${ }^{34}$ While a relative autonomization of interest politics from party politics seemed a possible outcome of political and economic change in these countries, in Turkey, after the AKP came to power in 2002, the political network relations that developed around the ruling party appeared as a salient characteristic of the new trends in the country's political economy. However, it would be difficult to describe the situation in Turkey as a case of the colonization of economic interests by the ruling party. What we observe may be better described as a form of interaction that involves a mutual dependency between the government and business. Business actors, both individual entrepreneurs and associations, have relied on government support in the pursuit of economic interest or associational power. At the same time, entrepreneurs used economic resources, and associations mobilized their influence on the membership to support the ruling political party.

The government's relations with the politically privileged big entrepreneurs are still unmediated by business associations. However, in the new business environment the frame of interest representation is no longer the same. The chambers and the voluntary business associations formed in the 1970s, TÜSIAD in particular, continue to be active, but their position in the business environment is now challenged by new business organizations.

The relations between AKP and TÜSIAD have been especially tense. Similar tensions have also had an impact on the way the government acts toward the chambers with a mixture of threats and attempts at co-optation. This differs from the warm relations the government has with voluntary business associations established and developed alongside 
the rise of political Islam since the 1990s. One such association is the Association of Independent Industrialists and Businessmen (Müstakil Sanayici ve Iss Adamları Derneği, MÜSİAD), which had close relations with the Welfare Party (Refah Partisi, RP), the only party representing political Islam in the 1990s. Two other voluntary business associations that we will be discussing in this book, the Association of Anatolian Businessmen (Anadolu Aslanları İş Adamları Derneği, ASKON) and the Turkish Confederation of Businessmen and Industrialists (Türkiye San-

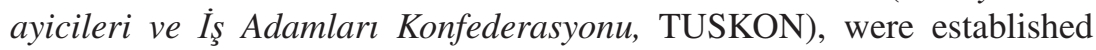
later and were again situated within the constituency of political Islam. These three associations positioned themselves against those previously established and played an important role in the emergence of a highly polarized business environment.

The government's favorable treatment of certain entrepreneurs and associations has been an important aspect of this polarization. The government's position vis-à-vis different entrepreneurs and associations has affected the relations within the business community and the relative power and influence of different business associations. The literature on corporatism explores the many ways that business associations are often shaped by the institutional features of the existing political order. ${ }^{35}$ In his study of Latin America, Schneider argues that society-specific forms of business organization need to be analyzed beyond the stable features of the institutional setting in which they are formed by taking into account the strategic actions of political actors seeking to modify and redefine these forms. ${ }^{36}$ Schneider's in-depth historical investigation of the ways in which Latin American governments organized and disorganized business throughout the twentieth century provides useful insights for the analysis of the politically driven character of the associational environment in Turkey.

In the Turkish example we also see, however, that business associations themselves act as agents in political processes that change the configuration of interests within the business community. Rather than representing exogenously given interests defined along the lines of the sectoral, regional and scalar characteristics of their constituency, they pursue strategies designed to bring their members into coherent communities of interest and outlook around macro-level socioeconomic projects with different implications for the type of economic and political development trajectory that the country would follow.

The new business associations situated in the political networks around the ruling AKP government have been very much part of an environment in which the place of religion in society and politics has changed, significantly reconfiguring organizational discourse and strategies. While 
religion has always been an element of Turkish politics, the rise of political Islam constitutes a process shaped not by the system of beliefs or institutions intrinsic to Islam, but rather by political actors who followed, adapted to and used the opportunities presented by changing circumstances.

\section{RELIGION AND THE "SPIRIT" OF THE NEW CAPITALISM}

Although it has been influentially argued that the retreat of religion from the public sphere and the realm of politics should not be considered an empirically valid historical phenomenon or a necessarily positive development from a normative point of view, ${ }^{37}$ it still remains difficult to argue that there is nothing surprising about the return of religion to the public sphere. In fact, Max Weber, after having made his seminal contribution to the analysis of the relationship between religion and capitalism, ended his last book, General Economic History, with the observation that "[ $\mathrm{t}]$ he religious root of modern economic humanity is dead." 38

Those who discussed Weber's work in the 1960s, such as Talcott Parsons or Maxime Rodinson, also believed that the role of religion in contemporary society could not be similar to the role Weber attributed to Protestantism in the development of modern Western capitalism because religion was becoming a private matter. ${ }^{39}$ As Rodinson observed in Islam and Capitalism, "Religion nowadays essentially appears in everyone's minds, as giving guidance to the individual's attitudes to supernatural values." 40

In the 1960s, scholars such as Parsons and Rodinson could easily take it for granted that the increasing privatization of religion was an accepted fact. Few social scientists or historians would adopt such an unqualified position today, given the intense debates on the "de-privatization" of religion or "post-secularism" in the cultural context of recent capitalist globalization. The following statement by Jürgen Habermas reflects this atmosphere: "Religious traditions and communities of faith have gained a new, hitherto unexpected political importance since the epoch making change of 1989-1990." ${ }^{41}$ We may argue that the change goes back further than 1989. In fact, already in 1986, in a review article on several books dealing with religion and politics in different societal contexts, Daniel H. Levine observed that the renewed prominence of religion has fostered widespread interest in the phenomenon and led to certain approaches that 
"attributed to religion all the decisive impact once reserved for Marxism or modernization." 42

This renewed prominence of religion could perhaps be explained with reference to the impact of capitalist globalization on individual lives, by arguing that the appeal of religion has become stronger for people trying to give meaning to and cope with social relations in a changing and highly uncertain environment. It could, in fact, be expected that both the feelings of resentment on the part of the disadvantaged and the need for the psychological reassurance of the legitimacy of the privileged ${ }^{43}$ would become more important in the context of the changes brought along by globalization and that they would lead people to seek shelter in organized religions. An Awareness of What is Missing ${ }^{44}$ in a world where the foundations of human solidarity appear increasingly fragile could, in itself, provide a strong enough explanation of the appeal of religion.

An investigation of the factors that affect and shape the way religion is manifested publicly lies beyond the scope of this book. We have limited ourselves to the observation that religion is an important element of the cultural and political environment of the new capitalism, as it informs social relations as well as political discourse and government policy. In this environment, religion could act as an ingredient of social capital that creates a basis of trust. ${ }^{45}$ Alternatively, it could become a point of reference in the politically motivated affirmations of ethnic divisions, ${ }^{46}$ or it could be seen as a source of international conflict and confrontation. ${ }^{47}$

In Turkey, there is a general tendency to construe the rise of political Islam as a reaction to Kemalism by "formerly oppressed" believers who currently make their presence felt in the public sphere. ${ }^{48}$ This interpretation is situated in a particular paradigm where the term "social engineering" is reserved for discussions of the cultural politics of modernizing states and not used with reference to the role of the myriad governmental groups and NGOs in influencing the place of the sacred in individual lives and affecting the interpretations of religion and manifestations of religiosity. ${ }^{49}$ But the type of social engineering that is rarely defined as such is precisely what one needs to consider in an analysis of the rise of political Islam in the way it was reflected in the Turkish business environment. Our study discusses the role of the government in the rising importance of religion in Turkish society. It also emphasizes the role of religious discourses and strategies used by business associations in the formation of the constituency of political Islam.

Religion has appeared as an element of the models of social, economic and political development around which these associations try to unite their members. In the process, they have used religion as a network resource for building relations of trust and solidarity among enterprises 
across sectoral, scalar or regional differences. Given the forms of productive organization characteristic of the new capitalist order, these differences have become less important than the relational matrix in which production is carried out. ${ }^{50}$ Vertically integrated and bureaucratically managed large enterprises no longer have the privileged position they once had within the production systems of the post-World War II period. They were downsized and decentralized, while their bureaucratic managerial practices were replaced with more "flexible" ones. At the same time, many SMEs, including those located in the less-developed regions, began to operate with different relations of input supply, contract sharing and subcontracting with each other and with larger enterprises - both domestic and foreign. ${ }^{51}$ Our analysis of the Turkish case shows that these developments did not lead to a decline in the significance of developed cities and large entrepreneurs operating at national and global levels. Instead, they involved a change in the relations among large enterprises and small ones that became important, extending their reach beyond local and national boundaries. In this context, the formation of networks among smaller and larger enterprises located in different regions is an important aspect of the activities of business associations. We will show that all business associations, including the big business association TÜSIAD, have been engaged in this type of activity. In fact, in the 1990s, TÜSIAD began to actively develop close relations with provincial enterprises of all sizes and was instrumental in the formation of sectoral and regional associations and their unification under an umbrella organization - the Turkish Enterprise and Business Confederation (Türk Girişim ve İs Dünyası Konfederasyonu, TÜRKONFED).

In this strategic orientation, the associations that used religion as a network resource have emphasized the discrimination that conservative Muslims faced in a business environment historically dominated by the secularist business establishment to strengthen the bonds among their members and to keep them within the constituency of political Islam. They also collaborate with other voluntary organizations of an Islamic character operating in other areas beyond the realm of business to form and contribute to the stability of networks in which economic and non-economic interests were pursued together.

The fact that the emergent "conservative Muslim bourgeoisie" has not experienced difficulty adapting to the new capitalist environment brings to the fore doubts concerning the validity of some institutionalist approaches that have sought to explain limitations to capitalist economic development stemming from the character of Islamic legal and bureaucratic institutions. ${ }^{52}$ These approaches could be critically assessed by observing that not only can institutions be modified to accommodate the 
requirements of economic life, but also certain forms of behavior informed by religious identity might have different economic consequences in different historical contexts. ${ }^{53}$

The use of religion as a network resource, which we observe in the Turkish case, has proceeded in the presence of the forms of productive organization and political action that have characterized the new capitalist order. In this particular environment, Islam did not seem to be inimical to capitalist entrepreneurial activity. However, it is important to acknowledge that the role of religion in this type of business development is quite different from the relationship between the Protestant ethic and capitalist development investigated by Weber.

One significant aspect of the role that religion plays in Weber's analysis of capitalist development concerns the ethics of internal and external relations. Weber argues that in traditional societies these two ethics are categorically distinct; different ethical norms and sanctions apply to the way one deals with or acts toward members of his own group, the fellow members of the household, clan, tribe, religious community, and toward "strangers." Protestantism introduced a different type of ethics that broke the barrier between the internal and the external with important economic and political implications. ${ }^{54}$ The disappearance of the dualistic ethics and the emergence of a universally binding morality opened the way to an ever-expanding sphere of economic relations with "strangers" by establishing the basis of trust and significantly eliminating uncertainty.

The impact made by the transition from traditional dualistic to universal ethics in capitalist development was not limited to the sphere of economics. It was also observed in what Collins calls the "citizenship revolution" whereby the formal legal rights and procedures acquired meaning and significance for all members of modern capitalist societies governed by the formal legal rationality of the state and the formal economic rationality of the business enterprise. ${ }^{55}$ It is especially in the General Economic History that we find Weber's ideas on modern citizenship, the bureaucratic legal state and the capitalist enterprise brought together in the cultural universe of Protestant ethics. ${ }^{56}$

Our analysis of the developments in Turkey shows that religion plays the role of a network resource for building trust in economic transactions between market participants and in their dealings with the government. Economic and political networks, which the affirmation of religious identity helps stabilize, include some economic actors while excluding others. In fact, the exclusion of the "other" becomes integral to the building of solidarity among "us." 
The role played by religion in the transformation of the Turkish business environment has been situated in a context of intra-class conflict. The cleavages within the business community pertain, first and foremost, to those between previously established entrepreneurs who emerged before 1980 and the ones who emerged later through the rise of political Islam and who continued to benefit from their privileged relations with the ruling AKP. Here, the affirmation of religious identity has appeared as an element informing the way the alliances and conflicts among different class actors are defined. The affirmation of religion in this sense has contributed to the polarization of the business environment.

\section{CONTINUITY AND CHANGE IN THE TURKISH BUSINESS ENVIRONMENT: FROM ONE POLITICALLY CREATED BOURGEOISIE TO ANOTHER}

Politically supported capital accumulation is a significant aspect of private sector development in twentieth-century Turkey. ${ }^{57}$ In fact, the nation-building agenda of both the Young Turk era in the early twentieth century and the founders of the Turkish republic emphasized the creation of a "national bourgeoisie" to replace the non-Muslim minorities who had dominated industry and commerce in the nineteenth-century Ottoman economy. A new class of entrepreneurs emerged and grew largely by relying on the state to raise the initial investment funds to have safe market outlets in a protected economy and to use cheap industrial inputs produced by the state-owned enterprises (SOEs).

We also see that the social legitimacy of business activity derived not from established views on property rights and the freedom of enterprise, but from the contribution that the private sector was expected to make to the economic development of the country. For a large part of republican history, at least until the 1980 s, the coordinates of the social position of big business were not firmly established. At the same time, there were serious economic uncertainties generated by the absence of a systematically pursued, coherent development strategy. These economic uncertainties were an important source of complaint for the big business community, which was also not happy with its vulnerability to political action.

In the aftermath of Turkey's insertion into the global economy, it became clear that the country would follow an outward-looking and market-oriented economic strategy where the central position of the private sector and big business could no longer be contested. This could 
be seen as the end of the history of the coming of age of the Turkish bourgeoisie, but it was not. Instead, we witnessed the emergence of a new vintage of politically created business actors who enjoyed favors defined by the new mechanisms of government intervention and deployed within networks that draw on cultural resources informed by religious identity. Can we, then, interpret this as the history of private sector development repeating itself in a different environment, leading to the replacement of one group of business people by another politically privileged one?

The legacy of the past clearly informed the attitudes of policy makers, shaped the expectations business people from the government and influenced relationships in the new setting. However, in an environment where the dynamics of government-business relations were clearly different and where the presence of previously established and economically very powerful class actors introduced new tensions in business politics, history could hardly be said to be repeating itself. The business environment continued to be marked by recurrent tensions now aggravated by the coexistence of competing models of capitalist development endorsed and promoted by different segments of the business community. These models incorporate perspectives on the regulatory framework of the economy, forms of social solidarity and the orientation of foreign economic relations.

Those members of the business community who remained outside the politically privileged networks operating with Islamic references, especially the established big business enterprises represented by TÜSIAD, called for a regulatory framework that would minimize the scope of political discretion. Their strategy for foreign economic relations was devised to maintain close relations with developed Western countries in general and the European Union (EU) in particular, in part because these relations required the establishment of - and respect for - a legal framework where the exercise of discretionary power by the government would be limited. While it was unlikely for them to advocate welfare state policies of the type shaped within the Keynesian demand management model, their views on industrial relations accepted organized interest representation by labor and a formal social policy approach in conformity with the prevailing European practices.

Another model of capitalist development took shape as the business actors close to the government opted for an economic policy that allowed a broader scope for discretionary political intervention into the economy. Under the AKP government, the new associations ceased to explicitly oppose Turkey's membership in the EU. ${ }^{58}$ However, they also took an active part in a foreign policy orientation different from Turkey's 
traditional Western-looking one, not only to protect those characteristics of the policy environment that allowed the use of different mechanisms of politically supported capital accumulation despite the criticisms of different international actors, such as the IMF or the European Commission (EC), but also because the development of economic relations with non-OECD (Organisation for Economic Co-operation and Development) countries was easier and hence more attractive for their constituency. Their approach to industrial relations, as well as to questions of inequality and poverty, were significantly shaped by references to Islamic norms of good conduct and social equity.

The implications of economic globalization for democracy have been discussed in several influential studies that have drawn attention to the fact that the limitation of national sovereignty - or the narrowing of the scope of policy action - by the forces of globalization could encumber not only economic development, but also the process of democratization. ${ }^{59}$ The case of Turkey shows that the impact of globalization on the political developments in a given country would be mediated by the role played by different business actors with their different ways of defining class interest. How interests are defined and pursued in different relations with the government might generate intra-class tensions strong enough to influence which model of capitalist development is pursued. In Turkey, the outcome of the conflicts and compromises that emerge in the presence of two competing models of capitalist development still remains uncertain. One may claim, however, that the outcome will have an important role in shaping the character of the political regime. As Schmitter has argued, the relationship between capitalism and democracy is far from being a simple, unidirectional one. ${ }^{60}$

\section{OUTLINE OF THE BOOK AND DATA SOURCES}

The reconfiguration of business interests and the emergence of new patterns in government-business relations in the post-1980 period, especially under the AKP, have taken place in an atmosphere of rupture that, in some ways, is reminiscent of the development of the private sector that began in the early republican period. The idea of opening a new page breaking ties with past trends - in economic and cultural relations is important in both contexts. In the ideological atmosphere of the post1980 period, the criticisms directed at the character of state-society relations in the earlier period were especially severe.

Chapter 1, "Economic development and cultural modernization in republican Turkey," presents the historical background for our analysis of 
the transformations that reshaped the business environment after Turkey's insertion into the global economy. In this chapter, we do not insist on the economic problems generated by heavy state intervention or the undemocratic nature of authoritarian secularization; instead, we explore the forms of state intervention that failed to play a market-sustaining role and draw attention to the limits of secularization. Our investigation of the political coordinates of private-sector development in Turkey attempts to lay bare the process of continuity and change in government-business relations in the post-1980 period. In a parallel vein, we examine the early historical trajectory of secularism in Turkey and discuss the national developmentalist phase of political Islam to draw attention, in Chapter 2, to the changing relationship between the economy and religion observed in different phases of Islamic politics.

Chapter 2, "The changing place of the economy and religion in Turkish society in the post-1980 period," first argues that Turkey was plagued by economic crises that emerged in the context of an unregulated market system and the political tensions generated by political Islam in the 1990s. The second section of the chapter explores the formation of the conservative liberalism of the AKP, which was informed by the economic and political crises of the 1990s. Despite the party's claim that radical elements of the Islamist movement were left behind and its full embrace of the principles of a liberal market economy and the basic tenets of democratic politics, the AKP government attempted to change the place of religion in society as well as to transform foreign economic relations. The discussion presented in this chapter shows that attempts to put the stamp of Islam on society were, in many ways, more successful than the incomplete secularization project undertaken by the early republican government during the single-party period.

Chapter 3, "The new political economy of capital accumulation," develops the argument that the transition from national developmentalism to economic liberalism in an open economy did not undermine the importance of government intervention in the economy. The chapter examines the opportunities for politically supported capital accumulation that emerged in the new framework of economic regulation. It also discusses how such opportunities determined the trajectories of business development by a group of entrepreneurs who had substantial business success during the rule of the AKP despite little previous business experience. In this context, we analyze the new dynamics of the relationship between politics and business, focusing on the ways that economic and political interests are articulated with each other and jointly pursued within a legal framework that is continuously modified to accommodate the required course of interest-motivated action. We also 
discuss the developments in the media sector to identify the implications of the new form of government-business relations for political democracy.

In Chapter 4, "Business associations as political actors," we examine the membership structures, the characteristics of organizational discourse and strategy and the nature of their relations with the political authority of five voluntary business associations: TÜSİAD, MÜSIAD, ASKON, TUSKON and TÜRKONFED. We explore the roles played by these associational actors in the reconfiguration of business interests and the emergence of competing models of capitalist development in a politically polarized society. We also draw attention to the continuing economic and political significance of the chambers, which often constitute an arena where the conflicts and alliances among voluntary associations are manifested.

After discussing the factors that explain the emergence of a polarized business environment, in Chapter 5 we explore the manifestations of polarization at the local level. The chapter begins with an investigation of the trends toward the relocation of industry and the current position of provincial towns in the Turkish economy to draw attention to the limits of regional economic development and the continued economic significance of İstanbul and its hinterland. This investigation shows that the challenge provincial economic development poses to the old metropoles should not be overestimated when analyzing cleavages within the business community.

Chapter 5 then examines the local business environment in three cities chosen for their economic and political characteristics. Two of them, Kayseri and Gaziantep, are prominent examples of newly emerging Anatolian industrial centers. During our research, both municipal governments were ruled by the AKP. İzmir, the third case, is an old industrial center whose economic adaptation to neoliberal globalization has not been very successful. This city is well known for its strong opposition to political Islam, in general, and the AKP, in particular.

In these three local business environments we observe political polarization in both the conflicts between central and local levels of government and in the tensions among local business actors. Where the relations between the central government and the municipality are tense, the strength of local coalitions or the local bases of trust that determine the "social capital" of the city might be quite ineffective in producing positive outcomes. As to the tensions among local political actors, they are managed with varying degrees of success, in part depending on the role played by individual business leaders who act in ways that either alleviate or aggravate these tensions. 
The concluding chapter recapitulates the arguments developed in the book and raises a series of questions about future possibilities for the political regime of Turkey and the position of the country in the global order. This chapter also discusses how the case of Turkey may be useful for the analysis of current patterns of private sector development and their political implications in other contexts.

The book is based on primary and secondary published sources as well as interviews with business representatives. In particular, we conducted an extensive analysis of four sources of data: changes in economic legislation, official documents, publications of different business associations and a survey of newspaper and journal coverage of business development, associational activity and government-business relations. We also conducted open ended, in-depth interviews with 34 representatives of business associations and 12 business people in İstanbul and the above-mentioned three cities. These interviews were designed to obtain factual information about the membership structures of business associations, their activities, as well as the ways in which alliances and conflicts among them manifest themselves, especially in elections for the national and local boards and committees of the chamber administrations.

\section{NOTES}

1. Karl Polanyi (1957a), "Economy as an Instituted Process," in Karl Polanyi, Conrad M. Arensberg and Harry W. Pearson (eds), Trade and Market in the Early Empires: Economies in History and Theory, Glencoe, IL: Free Press, pp. 243-270.

2. SSevket Pamuk (2008), "Globalization, Industrialization and Changing Politics in Turkey," New Perspectives on Turkey, (38), 267-273; Ayda Eraydın (1999), "Sanayinin Anadolu'ya Yaygınlaşması ve Son Dönem Gelişen Yeni Sanayi Odakları," in Oya Baydar (ed.), 75 Yılda Çarklardan Chip'lere, İstanbul: Tarih Vakfi, pp. 257-278; E. Fuat Keyman and Berrin Koyuncu Lorasdağ (2010), Kentler: Anadolu'nun Dönü̈sümü̈, Türkiye’nin Geleceği, İstanbul: Doğan Yayıncılık; Ahmet Haşim Köse and Ahmet Öncü (1998), "Dünya ve Türkiye Ekonomisinde Anadolu İmalat Sanayii: Zenginleşmenin mi Yoksa Yoksullaşmanın mı Eşiğindeyiz?" Toplum ve Bilim, (77), 135-159; Alpay Filiztekin and İnsan Tunalı (1999), "Anatolian Tigers: Are they for Real?" New Perspectives on Turkey, (20), 77-106.

3. For coverage of the subject in the popular press, see, for example, Süleyman Yaşar, "Tartışmanın Nedeni Anadolu Sermayesi," Sabah, 18 May 2012; Ömer Laçiner, "Evet'in Tarih Öncesi," Radikal 2, 5 September 2010; Hasan Bülent Kahraman, "Anadolu-İstanbul Meydan Muharebesi," Sabah, 15 September 2008.

4. M. Hakan Yavuz (2006), "Introduction: The Role of the New Bourgeoisie in the Transformation of the Turkish Islamic Movement," in M. Hakan Yavuz (ed.), The Emergence of A New Turkey: Democracy and AK Parti, Salt Lake City, UT: University of Utah Press, pp. 1-19; M. Hakan Yavuz (2009), Secularism and Muslim Democracy in Turkey, Cambridge and New York: Cambridge University Press, 2009; William Hale and Ergun Özbudun (2010), Islamism, Democracy and Liberalism in Turkey: The Case of the AKP, London and New York: Routledge; Ziya Öniş (2006), 
"Globalization and Party Transformation: Turkey's Justice and Development Party in Perspective," in Peter Burnell (ed.), Globalising Democracy: Party Politics in Emerging Democracies, London and New York: Routledge, pp. 122-140; Seda Demiralp (2009), "The Rise of Islamic Capital and the Decline of Islamic Radicalism in Turkey," Comparative Politics, 41 (3), 315-335; Şebnem Gümüşçü (2010), "Class, Status and the Party: the Changing Face of Political Islam in Turkey and Egypt," Comparative Political Studies, 43 (7), 835-861. The contributions to Ümit Cizre, ed. (2008), Secular and Islamic Politics in Turkey: The Making of Justice and Development Party (London and New York, Routledge, displays somewhat more critical approach to the policies of the AKP. For a book that insists on the Islamization of Turkish Society under the AKP rule, see Barry Rubin and Birol Yeşilada, eds (2012), Islamization of Turkey under the AKP Rule, London and New York, Routledge.

5. We would like to mention three authors in particular. Cihan Tuğal has discussed the role of political parties in actively constructing and contributing to the naturalization of religious identity and belonging. See Cihan Tuğal (2009), The Passive Revolution: Absorbing the Islamic Challenge to Capitalism, Stanford, CA: Stanford University Press. Haldun Gülalp has drawn attention to the influence of global multiculturalist discourse and the debates around the place of Islam in Turkish society. See Haldun Gülalp (1995), "Islamism and Postmodernism," Contention, 4 (2), 59-73 and Gülalp (1997), "Globalizing Postmodernism: Islamist and Western Social Theory," Economy and Society, 26 (3), 419-433. Mustafa K. Bayırbağ has insisted on the role of political factors and the nation-state in shaping regional economic development and mobilizing pro-business urban governance. See Mustafa K. Bayırbağ (2010), "Local Entrepreneurialism and State Re-scaling in Turkey," Urban Studies, 47 (2), 363-385 and Bayırbağ (2011), "Pro-Business Local Governance and (Local) Business Associations: The Case of Gaziantep," Business and Politics, 13 (4), article 6. DOI: 10.2202/1469-3569.1355.

6. See, in particular, David Harvey (2005), A Brief History of Neoliberalism, New York: Oxford University Press and Gerard Dumenil and Dominique Levy (2005), "The Neoliberal (Counter-) Revolution," in Alfredo Saad Filho and Deborah Johnston (eds), Neoliberalism: A Critical Reader, London and Ann Arbor, MI: Pluto Press, pp. 9-19. For the "organized" and "regulated" character of the post-World War II order preceding economic globalization, see Scott Lash and John Urry (1987), The End of Organized Capitalism, Madison, WI: University of Wisconsin Press and Giovanni Arrighi (1995), The Long Twentieth Century: Money, Power, and the Origins of Our Times, London and New York: Verso.

7. Stephan Haggard, Sylvia Maxfield and Ben Ross Schneider (1997), "Theories of Business and Business-State Relations," in Sylvia Maxfield and Ben Ross Schneider (eds), Business and the State in Developing Countries, Ithaca, NY: Cornell University Press, pp. 36-60; Leslie C. Gates (2009), "Theorizing Business Power in the Semiperiphery: Mexico 1970-2000," Theory and Society, 38 (1), 57-95.

8. Karl Polanyi (2001 [1944]), The Great Transformation: The Politics and Economic Origins of Our Time, Boston, MA: Beacon Press, p. 159.

9. Peter A. Hall and David Soskice, eds (2001), Varieties of Capitalism: The Institutional Foundations of Comparative Advantage, Oxford and New York: Oxford University Press. For a collection of articles that brings together different approaches to the VoC debate, see Bob Hancké, ed. (2009), Debating Varieties of Capitalism: A Reader, Oxford and New York: Oxford University Press. For a critical evaluation, see also Kathleen Thelen (2012), "Varieties of Capitalism: Trajectories of Liberalization and the New Politics of Social Solidarity," Annual Review of Political Science (15), $137-159$.

10. See, especially, Vivien A. Schmidt (2009), "Putting the Political Back into the Political Economy by Bringing the State Back In Yet Again," World Politics, 61 (3), 
516-546. For other articles that are critically engaged with VoC in order to analyze the other varieties of capitalism in the developing world, see Ben Ross Schneider (2009), "Hierarchical Market Economies and Varieties of Capitalism in Latin America," Journal of Latin American Studies, 41 (3), 553-575 and Andreas Nölke and Arjan Vliegenthart (2009), "Enlarging Varieties of Capitalism: the Emergence of Dependent Market Economies in Central Europe," World Politics, 61 (4), 670-702.

11. For the limitations of the original $\mathrm{VoC}$ approaches in dealing with the historical changes, see, in particular, Glenn Morgan, Richard Whitley and Eli Moen, eds (2005), Changing Capitalisms? Internationalization, Institutional Change, and Systems of Economic Organizations, Oxford and New York: Oxford University Press and Wolfgang Streeck (2011), "E Pluribus Unum? Varieties and Commonalities of Capitalism," in Mark Granovetter and Richard Swedberg (eds), The Sociology of Economic Life, Boulder, CO: Westview, 3rd edition, pp. 419-455.

12. Wolfgang Streeck and Kathleen Thelen, (2005), "Introduction: Institutional Change in Advanced Political Economies," in Wolfgang Streeck and Kathleen Thelen (eds), Beyond Continuity: Institutional Change in Advanced Political Economies, Oxford and New York, Oxford University Press, pp. 1-39; Colin Hay, (2005), "Two Can Play at that Game ... Or Can They?" in David Coates (ed.), Varieties of Capitalism, Varieties of Approaches, Basingstoke: Palgrave, pp. 106-122; and Streeck, "E Pluribus Unum? Varieties and Commonalities of Capitalism." For a discussion of ideas and discursive practices, especially see Vivien A. Schmidt (2010), "Taking Ideas and Discourse Seriously: Explaining Change through Discursive Institutionalism as the Fourth 'New Institutionalism'," European Political Science Review, 2 (1), $1-25$. For the importance of ideas in shaping the politics of institutional change, see Peter A. Hall, ed. (1989), The Political Power of Economic Ideas: Keynesianism Across Nations, Princeton, NJ: Princeton University Press; Mark Blyth (2002), Great Transformations: Economic Ideas and Institutional Change in the Twentieth Century, Cambridge and New York: Cambridge University Press; Dani Rodrik (2011), The Globalization Paradox: Democracy and the Future of the World Economy, New York and London: W.W. Norton \& Company.

13. For an extensive discussion of the historical institutionalist methodology, see Sven Steinmo (2008), "Historical Institutionalism," in Donatella Della Porta and Michael Keating (eds), Approaches and Methodologies in the Social Sciences: A Pluralist Perspective, Cambridge and New York: Cambridge University Press, pp. 118-138.

14. The most typical manifestation of such a social imagination in the social sciences is the effort to understand the laws governing the economy as a spontaneous order functioning on the basis of the rational pursuit of interest. We find a thorough criticism of this type of approach to the relationship between politics and society in Karl Polanyi's The Great Transformation: The Politics and Economic Origins of Our Time, as well as Polanyi (1957b), "Aristotle Discovers the Economy," in Trade and Market in the Early Empires: Economies in History and Theory, pp. 64-94 and "Economy as an Instituted Process." For other critical approaches, see also Sheldon S. Wollin (1960), Politics and Vision, Boston, MA: Little, Brown and Company and Margaret Somers (2001), "Romancing the Market, Reviling the State: Historicizing Liberalism, Privatization, and the Competing Claims to Civil Society," in Colin Crouch, Klaus Eder and Damian Tambini (eds), Citizenship, Markets and the State, Oxford and New York: Oxford University Press, pp. 23-48.

15. Albert O. Hirschman (1991), The Rhetoric of Reaction: Perversity, Futility, Jeopardy, Cambridge, MA: The Belknap Press of Harvard University Press.

16. World Bank (1997), World Development Report 1997: The State in a Changing World, Washington, DC: World Bank. For a critical evaluation of this transition, see Dani Rodrik (2006), "Goodbye Washington Consensus, Hello Washington Confusion? A Review of the World Banks's Economic Growth in the 1990s: Learning From 
a Decade of Reform," Journal of Economic Literature, 44 (4), 973-987 and Ziya Öniş and Fikret Şenses (2005), "Rethinking the Emerging Post-Washington Consensus," Development and Change, 36 (2), 263-290.

17. Carlos Santiso (2001), "Good Governance and Aid Effectiveness: The World Bank and Conditionality," Georgetown Public Policy Review, 7 (1), 16.

18. Joseph E. Stiglitz (1999), "The World Bank at the Millennium," The Economic Journal, 109 (459), 577-597.

19. Polanyi, The Great Transformation, p. 146.

20. Ibid., pp. 45-58.

21. Susan Strange (1996), The Retreat of the State: The Diffusion of Power in the World Economy, Cambridge and New York: Cambridge University Press.

22. Neil Brenner (2004), New State Spaces: Urban Governance and the Rescaling of Statehood, Oxford and New York: Oxford University Press. For a critique, see Kevin R. Cox (2009), "'Rescaling the State' in Question," Cambridge Journal of Regions, Economy and Society, 2 (1), 107-121.

23. Bob Jessop (2003), The Future of the Capitalist State, Malden, MA: Polity Press, pp. 199-200.

24. Bob Jessop and Ngai-Ling Sum (2006), Beyond the Regulation Approach: Putting Capitalist Economies in Place, Cheltenham, UK and Northampton, MA: Edward Elgar.

25. Jamie Peck and Nik Theodore (2007), "Variegated Capitalism," Progress in Human Geography, 31 (6), 731-772; Neil Brenner, Jamie Peck and Nik Theodore (2010), "Variegated Neoliberalization: Geographies, Modalities, Pathways," Global Networks: A Journal of Transnational Affairs, 10 (2), 182-222.

26. Béatrice Hibou, ed. (1999), Privatising the State, London: C. Hurst.

27. Wolfgang Streeck (2009), Re-forming Capitalism: Institutional Change in German Political Economy, Oxford and New York, Oxford University Press.

28. For a discussion of different aspects of the changing boundaries of politics, see the contributions in Charles S. Maier, ed. (1987), Changing Boundaries of the Political: Essays on the Evolving Balance between the State and Society, Public and Private in Europe, Cambridge and New York: Cambridge University Press.

29. Neera Chandhoke (2001), "The 'Civil' and the 'Political' in Civil Society," Democratization, 8 (2), 1-24; Jonah D. Levy (1999), Tocqueville's Revenge: State, Society, and Economy in Contemporary France, Cambridge, MA: Harvard University Press.

30. Levy, Tocqueville's Revenge, pp. 6, 9.

31. The historical legacy of state-dominated private sector development is important to take into account in analyses of the responses to economic globalization in late industrializing countries. See Gates, "Theorizing Business Power in the Semiperiphery: Mexico 1970-2000." Different studies on the role of the state in the process of capital accumulation in these countries include: Ayşe Buğra (1994), State and Business in Modern Turkey: A Comparative Study, Albany: State University of New York; Alice H. Amsden (2001), The Rise of "The Rest": Challenges to the West From Late-Industrializing Economies, Oxford and New York: Oxford University Press; Eun Mee Kim (1997), Big Business, Strong State: Collusion and Conflicts in South Korean Development, 1960-1990, Albany, NY: State University of New York Press; Sylvia Maxfield and Ben Ross Schneider, eds, Business and the State in Developing Countries; Dennis L. McNamara, ed. (2002), Corporatism and Korean Capitalism, London and New York: Routledge; and Ben Ross Schneider (2004), Business and Politics in Twentieth-Century Latin America, Cambridge and New York: Cambridge University Press.

32. Philippe C. Schmitter (1974), "Still the Century of Corporatism?" Review of Politics, (36), 105. For a re-evaluation of his original argument, see Philippe C. Schmitter (2010), "Business and Neo-Corporatism," in David Coen, Wyn Grant and Graham 
Wilson (eds), The Oxford Handbook of Business and Government, Oxford and New York: Oxford University Press, pp. 248-261. For an analysis of the institutional frame of interest representation through political development of Turkey, see Robert Bianchi (1984), Interest Groups and Political Development in Turkey, Princeton, NJ: Princeton University Press.

33. For a comparison of the terms of this partnership in the Turkish and South Korean cases where it was an important characteristic of private sector development, see Buğra, State and Business in Modern Turkey, pp. 19-33.

34. Wyn Grant (1989), "Government-Industry Relations in Britain, Germany and Italy: The Company State, Associative State and Party State," Universität Constanz, Lecture at Sozialwissenschaftliche Fakultät, Sonderforschungsbereich 221; Orazio Lanza and Kostas Lavdas (2000), "The Disentanglement of Interest Politics: Business Associability, the Parties and Policy in Italy and Greece," European Journal of Political Research, 37 (2), 203-235.

35. Wolfgang Streeck (2006), "The Study of Organized Interests: Before 'the Century' and After," in Colin Crouch and Wolfgang Streeck (eds), The Diversity of Democracy: Corporatism, Social Order and Political Conflict, Cheltenham, UK and Northampton, MA: Edward Elgar, pp. 3-45; Schneider, Business Politics and the State in Twentieth-Century Latin America.

36. Schneider, Business Politics and the State in Twentieth-Century Latin America.

37. See, especially, José Casanova (1994), Public Religions in the Modern World, Chicago, IL: University of Chicago Press; Casanova (2008), "Public Religion Revisited," in Hent de Vries (ed.), Religion Beyond the Concept, New York: Fordham University Press, pp. 101-119.

38. Max Weber (1981, [1927]), General Economic History, New Brunswick, NJ and London: Transaction Publishers, p. 369.

39. Talcott Parsons (1964, [1922]), "Introduction" to Max Weber, The Sociology of Religion, Boston, MA: Beacon Press.

40. Maxime Rodinson (2007[1966]), Islam and Capitalism, London: Saqi Essentials, p. 286.

41. Jürgen Habermas (2006), "Religion in the Public Sphere," European Journal of Philosophy, 14 (1), 1.

42. Daniel H. Levine (1986), "Religion and Politics in Comparative and Historical Perspective," Comparative Politics, 19 (1), 95.

43. Weber, Sociology of Religion, pp. 106-108.

44. Jürgen Habermas et al. (2010), An Awareness of What Is Missing: Faith and Reason in a Post-Secular Age, Cambridge and Malden, MA: Polity.

45. Robert D. Putnam (1993), Making Democracy Work: Civic Traditions in Modern Italy, Princeton, NJ: Princeton University Press; Putnam (2000), Bowling Alone: The Collapse and Revival of American Community, New York: Simon \& Schuster. See also Corwin Smidt, ed. (2003), Religion as Social Capital: Producing the Common Good, Waco, TX: Baylor University Press.

46. On this, especially see Chandhoke, "The 'Civil' and the 'Political' in Civil Society," and Cedric de Leon, Manali Desai and Cihan Tu (2009), "Political Articulation: Parties and the Constitution of Cleavages in the United States, India, and Turkey," Sociological Theory, 27 (3), 193-219.

47. Samuel P. Huntington (1996), The Clash of Civilizations and the Remaking of World Order, New York: Simon and Schuster.

48. We find a critical evaluation of the approaches that reflect this tendency in Gülalp's works where he draws attention to the influence of global multiculturalist discourse and the debates around the place of Islam in Turkish society. See Gülalp, "Islamism and Postmodernism" and "Globalizing Postmodernism: Islamist and Western Social Theory." 
49. A strong argument against the idea of "naturalness" of religion can be found in Wuthnow's discussion of the role played by different organizations that "produce the sacred" in the American context. See Robert Wuthnow (1994), Producing the Sacred: An Essay on Public Religion, Urbana, IL and Chicago, IL: University of Illinois Press. For a discussion of the role of political parties in actively constructing and contributing to the naturalization of religious identity and belonging, see de Leon, Desai and Tuğal, "Political Articulation: Parties and the Constitution of Cleavages in the United States, India, and Turkey."

50. See Jessop and Sum, Beyond the Regulation Approach.

51. Ash Amin, ed. (1994), Post-Fordism: A Reader, Oxford and Cambridge, MA: Blackwell; Michael J. Piore and Charles F. Sabel (1984), The Second Industrial Divide: Possibilities for Prosperity, New York: Basic Books; Gary Gereffi (1995), "The Global Commodity Chains," in Barbara Stallings (ed.), Global Change, Regional Response: The New International Context of Development, Cambridge and New York: Cambridge University Press, pp. 100-142.

52. See, in particular, Timur Kuran (2003), "The Islamic Economic Crisis: Institutional Roots of Economic Underdevelopment in the Middle East," Journal of Economic History, 63 (2), 414-464 and Kuran (2010), The Long Divergence: How Islamic Law Held Back the Middle East, Princeton, NJ: Princeton University Press. Bryan Turner argues that one of the interpretations of Weber's views on the connection between religious beliefs and capitalist development that focuses on patrimonial bureaucracy as a characteristic of Islamic institutions finds support in most historical researches. See Bryan S. Turner (1974), "Islam, Capitalism and the Weber Thesis," British Journal of Sociology, 25 (2), 230-243.

53. This argument is systematically pursued by Rodinson in Islam and Capitalism.

54. Weber, General Economic History, pp. 356-369.

55. Randall Collins (1980), "Weber's Last Theory of Capitalism: A Systematization," American Sociological Review, 45 (6), 933. See also Stephen Kalberg (1980), "Max Weber's Types of Rationality: Cornerstones for the Analysis of Rationalization Processes in History," American Journal of Sociology, 85 (5), 1145-1179.

56. Max Weber, General Economic History, especially see Chapter 28 on Citizenship, pp. 315-337.

57. On this, see Buğra, State and Business in Modern Turkey.

58. Contrary to some expectations, under the AKP government the accession process continued albeit without much determination to combat the obstacles against it in a constructive fashion.

59. Among them, see Claude E. Barfield (2001), Free Trade, Sovereignty, Democracy: The Future of the World Trade Organization, Washington, DC: AEI Press and Rodrik, The Globalization Paradox.

60. Philippe C. Schmitter (1992), "The Consolidation of Democracy and Representation of Social Groups," American Behavioral Scientist, 35 (4/5), 422-449. 